\title{
Новое поколение прав человека: соматические права
}

\author{
Абаиидзе A.A. * \\ Солниев $A . M^{* *}$
}

История развития концепции прав человека говорит нам о том, что появление каждого нового поколения прав человека обусловлено определенными коренными изменениями в обществе, сменой мировоззренческих установок. Одним из главных достижений второй половины XX века стало развитие науки, техники и производства. Однако научно-технический прогресс имеет свои положительные и отрицательные стороны. С одной стороны, развитие науки и техники принесло улучшение уровня жизни, новые рабочие места, но с другой стороны, достижения медицины, генетики, биологии и химии поставили общество в качественно иное состояние. У человека появилась реальная возможность не только улучшать мир вокруг, но изменить самого себя, весь человеческий род. Он получил возможность прекращать свою жизнь или жизнь родных ему людей (эвтаназия, аборт по причине предрасположенности плода к болезням), участвовать в выборе пола, как своего, так и зачинаемого ребенка. Работодатель на основании генетических данных, свидетельствующих о болезни потенциального работника, может отказать в приеме на работу. Люди одного пола могут вступать в брак и усыновлять ребенка либо благодаря репродуктивным технологиям иметь своего ребенка. Для поддержания жизни человека, для обновления и омоложения организма можно использовать стволовые клетки; наиболее простым способом их изыскания являются человеческие эмбрионы. В ближайшем будущем наука позволит клонировать человека, и появление двух генетически идентичных, но душевно различных людей приведет к целому комплексу проблем, в т.ч. и правовых. Изучение генома человека стало причиной того, что некоторые ученые позволяют себе делать заявления об обнаружении «гена преступности», наличие которого напрямую ведет к генетической дискриминации, хотя человек с подобным геном может прожить всю жизнь и не совершить ни одного преступления, а может,

\footnotetext{
* Абашидзе Анна Аслановна - студентка 6 курса медицинского ф-та РУДН.

** Солнцев Александр Михайлович - к.ю.н., преподаватель международного права юридического ф-та РУДН.
} 
к примеру, и вывести в будущем вакцину против СПИДа. Деление человеческих генов на «плохие» и «хорошие» является поводом к выведению «идеальных людей». Перечисленные примеры лишь капля в море сравнительно с надвигающейся на нас будущей неизвестностью‥ Между тем нельзя забывать, что наука - лишь одно из средств постижения мира, которое в настоящее время пользуется наибольшей популярностью. Однако сами ученые отмечают пределы научного познания; так, отделив «ген преступности», можно нарушить всю генетическую систему человека. Ученые далеки от познания всей сложности и многогранности мира, она доступна лишь Творцу этого мира. Применительно к сказанному право как система норм и институтов должно предохранять общество от разрушения его многовековых основ. Так, например, законодательное разрешение однополой семье иметь ребенка влечет за собой нарушение права ребенка на разнополых родителей, являющихся основой его гармоничного развития. Семья в настоящее время продолжает являться основой общества, и правовые нормы, устанавливаемые государством, не должны способствовать «размытию» традиционного понятия семьи.

Все вышеперечисленные примеры свидетельствуют о том, что в настоящее время можно выделить и обособить группу таких прав человека, которые основываются на фундаментальной мировоззренческой уверенности в «праве» человека самостоятельно распоряжаться своим телом: осуществлять его «реставрацию», изменять функциональные возможности организма. Права эти, имеющие сугубо личностный характер, можно определить как «соматические» (от греч. soma - тело). Под соматическими правами следует понимать признанную обществом и государством возможность определенного поведения, выражающуюся в полномочиях по распоряжению человеком своим телом. То есть это соматические притязания, получившие признание общества и правовое закрепление. Формы правового закрепления и наименования данных прав могут быть различны, возможно установление определенных правовых ограничений на их использование, главное здесь - принципиальное признание права. Исчерпывающий перечень соматических притязаний человека и основанных на них соматических

${ }^{1}$ Подробнее об этой проблеме см.: Барбур И. Этика в век технологии. М., 2001; Биология и культура. М., 2004; Фукуяма Ф. Наше постчеловеческое будущее: последствия биотехнологической революции. М., 2004; Гнатик Е.Н. Человек и его перспективы в свете антропогенетики: философский анализ. М.: Изд-во РУДН, 2005. 
прав составить достаточно сложно. Приведем классификацию соматических прав, разработанную М.А. Лавриком²:

1) право на смерть;

2) права человека относительно его органов и тканей;

3) сексуальные права человека (возможность искать, получать и передавать информацию, касающуюся сексуальности, сексуальное образование, выбор партнера, возможность решать, быть человеку сексуально активным или нет, самостоятельное решение вопроса о добровольных сексуальных контактах, вступлении в брак);

4) репродуктивные права человека (позитивного характера: искусственное оплодотворение и негативного характера: аборт, стерилизация, контрацепция) ${ }^{3}$;

5) право на перемену пола;

6) право на клонирование как всего организма так и отдельных органов;

7) право на употребление наркотиков и психотропных веществ.

Теоретическая разработка соматических прав человека началась в рамках конституционного права (В.И. Крусс, М.А. Лаврик) ${ }^{4}$, теории права и философии права (А.И. Ковлер, О.Э. Старовойтова) ${ }^{5}$. В международном праве данная категория прав обычно обозначается как

2 Лаврик М.А. К теории соматических прав человека // Сибирский юридический вестник. 2005. № 3. С. 24-25.

3 См.: Рашидханова Д.К. Репродуктивные права личности: сущность и правовая природа // Социальное и пенсионное право. 2007. № 4.

${ }_{4}^{4}$ Крусс В.И. Личностные («соматические») права человека в конституционном и философско-правовом измерении: к постановке проблемы // Государство и право. 2000. № 10. С. 43-50; Лаврик М.А. Права человека: новации в понимании и юридической фиксации // Электронный журнал «Российское право в Интернете». 2005 (03). Лаврик М.А. Правое Тело. Соматические права человека: взгляд из Сибири. Иркутск: Изд-во Иркут. ун-та, 2007; Лаврик М.А. Гарантии конституционных прав человека: соматический аспект: Дис. ... канд. юрид. наук. 12.00.02. Иркутск, 2006.

${ }^{5}$ Старовойтова О.Э. Юридический механизм реализации и защиты соматических прав человека и гражданина в Российской Федерации (историко-правовой и теоретический анализ). Дис. ... Д-ра юрид. наук. 12.00.01. С.-Пб., 2006; Старовойтова О.Э. Соматические права и генетический риск // Конституционное общество и проблемы совершенствования законодательства. Сб. научн. трудов. С.-Пб.: Изд-во ГУАП, 2007. С. 58-62; Ковлер А.И. Антропология права: 
«защита прав человека в сфере биоэтики», «права человека и развитие биологии и медицины» (А.Х. Абашидзе и А.М. Солнцев, А. И. Йорыш, С.И. Глушкова) ${ }^{6}$.

Поколение соматических прав человека представляет собой единую систему прав, имеющих ряд концептуальных отличий от других категорий прав. Как отмечает основоположник теории соматических прав профессор В.И. Крусс7 , природа «соматических» прав крайне своеобразна: здесь человек не только претендует на радикальное изменение первородной телесной целостности, но также выдвигает определенные претензии обществу. Своеобразен и предмет правовых притязаний: будучи лишь отчасти материальным, он вместе с тем принципиально определен персональными характеристиками правообладателя 8 . Все это дает возможность говорить о формировании нового поколения прав человека, отличающегося от трех известных поколений (личные и политические права; социально-экономические и культурные права; право солидарности).

Для уяснения становления и развития теории соматических прав человека необходимо отметить, что утверждение этой теории происходило параллельно с развитием биоэтики, которая оказала большое влияние на указанные права. Впервые термин «биоэтика» появился в научной литературе в 1970 г. в статье американского онколога Ванна Ренсселера Поттера под названием «Биоэтика: наука выживания» 9 . Биоэтика - сравнительно новая дисциплина, соединяющая в себе био-

Учебник для вузов. М.: Издательство НОРМА, 2002. (Глава 14. Личностные права: есть ли пределы?).

6 Абашидзе А.Х., Солнцев А.М. Нюрнбергский кодекс и дальнейшее международноправовое регулирование вопросов биоэтики // Российский ежегодник международного права. 2006. СПб., 2007. С. 122-133; Глушкова С.И. Права человека в России: Учебное пособие. М., 2005. С. 363-391; Йорыш А.И. Правовые и этические проблемы клонирования человека // Государство и право. 1998. № 11.

7 Крусс Владимир Иванович - доктор юридических наук, профессор, заведующий кафедрой теории права юридического факультета Тверского государственного университета.

8 См.: Сланов О.Т., Цалиев А.М. Право на телесную, физическую свободу человека в контексте теории соматических прав // Право и политика. 2008. № 2. C. 400-403.

9 Potter V.R. Bioethics: the sciense of survival // Perspectives in biology and medcine.1970. 14 (1). Р. 127-153. Позднее эта работа стала первой главой его книги «Биоэтика - мост в будущее»: Potter V.R. Bioethics: bridge to the future. Englewood Cliffs (NJ), Prentice Hall. 1971. 
логические знания и познание системы человеческих ценностей, это мультидисциплинарная область исследования условий и последствий научно-технического прогресса в биомедицине. Иными словами, биоэтика способна совместить и сопоставить право и мораль, поставить ограничения для развития соматических прав. Взаимосвязь соматических прав и биоэтики нашла свое отражение в правовых актах.

Каждый из элементов концепции соматических прав заслуживает отдельного рассмотрения, мы ограничимся лишь рассмотрением вопросов, какие международные организации участвуют в развитии соматических прав и какие важные международные документы созданы в этой сфере.

Международно-правовое регулирование отдельных аспектов концепции соматических прав человека происходит в рамках таких международных организаций, как ООН, Организация ООН по образованию, науке и культуре (ЮНЕСКО) и Совет Европы. В системе ООН можно отметить процесс обсуждения и принятия документов в сфере соматических прав, таких как, в частности резолюция ЭКОСОС 2001/39 «Генетическая конфиденциальность и недискриминация» от 26 июля 2004 г., резолюция Комиссии по правам человека 2003/69 «Права человека и биоэтика» от 25 апреля 2003 г. Особо стоит отметить процесс обсуждения (с 2001 г.) проекта международной конвенции ООН против клонирования человека в рамках Шестого комитета (юридический) Генеральной Ассамблеи ООН. В результате отсутствия консенсуса среди государств в 2005 г. была принята не конвенция, а Декларация ООН о клонировании человека ${ }^{10}$, при том что 84 члена ООН проголосовали «за» и 34 - «против» ${ }^{11}$. Камнем преткновения является вопрос о том, следует ли запретить все виды клонирования человеческих клеток, в том числе и терапевтическое клонирование, или только клонирование в целях воспроизводства человека. США и ряд других

10 См. Резолюцию Генеральной Ассамблеи ООН 59/280 от 08.08.2005 г. Подробнее об обсуждении проекта Международной конвенции против клонирования человека в целях воспроизводств см.: www.un.org/russian/documen/ convents/cloning.

11 Белоруссия, Бельгия, Бразилия, Болгария, Камбоджа, Канада, Китай, Куба, Кипр, Чешская Республика, КНДР, Дания, Эстония, Финляндия, Франция, Габон, Исландия, Индия, Ямайка, Япония, Лаос, Латвия, Литва, Люксембург, Нидерланды, Новая Зеландия, Норвегия, Республика Корея, Сингапур, Испания, Швеция, Таиланд, Тонга и Великобритания. 
стран выступают за полный запрет клонирования человека, им противостоит блок государств (преимущественно страны Европы), которые выступают за частичный запрет, предлагая разрешить клонирование в терапевтических целях.

Согласно положениям Декларации о клонировании человека 2005 г. государства - члены ООН призывают государства:

- $\quad$ принять все меры, необходимые для соответствующей защиты человеческой жизни в процессе применения биологических наук;

- запретить все формы клонирования людей в такой мере, в какой они несовместимы с человеческим достоинством и защитой человеческой жизни;

- принять меры, необходимые для запрещения использования методов генной инженерии, которые могут противоречить человеческому достоинству;

- принять меры для предотвращения эксплуатации женщин в процессе применения биологических наук.

Согласно п. (е) указанной Декларации, государства - члены ООН призывают безотлагательно принять и осуществить национальные законы для обеспечения выполнения указанных мер.

ЮНЕСКО также занимает активную позицию по международноправовому регулированию некоторых аспектов соматических прав человека и биоэтики. Программа ЮНЕСКО по биоэтике была основана в 1993 г., а с 2002 г. она является одним из приоритетных направлений деятельности ЮНЕСКО. В рамках Программы функционируют два совещательных органа: Международный комитет по биоэтике (МКБ), состоящий из 36 независимых экспертов ${ }^{12}$, которые следят за тем, чтобы при проведении научных исследований оставался незыблемым принцип уважения достоинства каждого человека и его прав, и Межправительственный комитет по биоэтике (МПКБ), состоящий из представителей 36 стран - членов ЮНЕСКО (Россия избрана до 2011 г.), которые встречаются как минимум раз в 2 года с целью проведения анализа рекомендаций МКБ. МПКБ уведомляет МКБ о своих решениях и представляет их, а также предложения по реализации решений на рассмотрение Генеральному директору ЮНЕСКО для последующей передачи государствам-членам, Исполнительному комитету и Генеральной конференции.

12 От России на 2008-2011 гг. избрана д.м.н, профессор, руководитель клинического отдела НИИЭМ им. Пастера О.И. Кубарь. 
Важным практическим результатом реализации Программы явилось принятие Всеобщей декларации о геноме человека и правах человека в 1997 г. на 29-й сессии Генеральной конференции ЮНЕСКО. В 2003 г. была принята Декларация о генетических данных человека $^{13}$, а в 2005 г. - Всеобщая декларация о биоэтике и правах человека $^{14}$, которая носит подлинно новаторский характер, в особенности ее положения, касающиеся социальной ответственности, доступа к качественным медицинским услугам, неприкосновенности и конфиденциальности частной жизни, совместного использования благ ${ }^{15}$.

Совет Европы (CE) - региональная международная организация, объединяющая 46 государств Европы. Регулирование соматических прав человека осуществляется СЕ в различных формах: путем принятия Рекомендаций Комитетом министров СЕ и Парламентской Ассамблеей СЕ (ПАСЕ), путем принятия международных конвенций, а также в судебном порядке - путем принятия решений Европейским Судом по правам человека (ЕСПЧ).

В рамках Совета министров СЕ принято более 25 рекомендаций по таким вопросам, как: создание банков пуповинной крови, торговля человеческими органами, вопрос ксенотрансплантологии, защита медицинских данных и т.д., и около 20 рекомендаций ПАСЕ по таким вопросам, как: биотехнологии и интеллектуальная собственность, защита генома человека, стволовые клетки, психиатрия и права человека и т.д. ${ }^{16}$.

Важно отметить, что единственным обязательным документом в сфере международно-правового регулирования соматических прав является Конвенция о защите прав и достоинства человека в связи с применением достижений биологии и медицины (Конвенция о правах человека и биомедицине), принятая в г. Овьедо 4 апреля 1997 г. ${ }^{17}$ с тремя протоколами: дополнительный протокол, касаю-

13 Солнцев А.М. Декларация о генетических данных человека (перевод, предисловие) // Международное право - International law. 2004. № 3 (19). С. 239-271.

14 Текст см.: Резолюция 36, принятая Генеральной конференцией ЮНЕСКО на ее 33-й сессии «Всеобщая декларация о биоэтике и правах человека» от 19 октября 2005 г. // Московский журнал международного права. 2006. № 2 (62). С. 259-272.

15 Володин В.П. Комментарий к материалам Тридцать третьей сессии Генеральной конференции ЮНЕСКО 2005 г. // Московский журнал международного права. 2006. № 2 (62). С. 256.

16 Подробнее см.: Texts of the Council of Europe on bioethical matters. v.I-II. Strasbourg, July 2004.

17 Конвенция вступила в силу 01.12.1999 г. На 01.10.2008 г. Конвенцию ратифицировали 22 государства. 
щийся запрещения клонирования человеческих существ (Париж, 12 января 1998 г.) $)^{18}$, дополнительный протокол относительно трансплантации органов и тканей человека (Страсбург, 24 января 2002 г.) $)^{19}$ и дополнительный протокол в области биомедицинских исследований (Страсбург, 25 января 2005 г.) ${ }^{20}$. Все указанные документы вступили в юридическую силу.

В соответствии с Конвенцией о правах человека и биомедицине государства-участники обязуются защищать достоинство и индивидуальность каждого человеческого существа, гарантировать каждому уважение целостности и неприкосновенности его личности и соблюдение других прав и основных свобод при использовании достижений биологии и медицины. Среди прав и свобод человека, которые защищает Конвенция, необходимо отметить прежде всего следующие: право на выбор вмешательства или невмешательства в сферу своего здоровья - данное вмешательство возможно только при свободном и осознанном согласии человека, основанном на информированности (ст. 5); право каждого на уважение его частной жизни в сфере, касающейся сведений о его здоровье (п. 1 ст. 10); право каждого на ознакомление с любой собранной информацией о состоянии его здоровья (п. 2 ст. 10); запрет дискриминации личности на основании ее генетических особенностей (ст. 11); запрет на использование вспомогательных репродуктивных технологий в целях выбора пола будущего ребенка, исключением являются случаи их использования для предотвращения тяжелого заболевания, наследуемого вместе с полом (ст. 14); право лиц, выступающих в качестве испытуемых, на информацию о своих правах и гарантиях своей защиты (ст. 16); запрет создания эмбрионов человека в исследовательских целях (п. 2 ст. 18); запрет на использование тела человека и частей его тела для извлечения финансовой выгоды (ст. 21); право каждого на судебную защиту в случае нарушения прав, признанных Конвенцией (ст. 23).

Для контроля за выполнением государствами-участниками положений Конвенции, внесения поправок и применения Конвенции

18 Протокол вступил в силу 01.03.2001. На 01.10.2008 г. Протокол ратифицировали 17 государств.

19 Протокол вступил в силу 01.05.2006. На 01.10.2008 г. Протокол ратифицировали 8 государств.

20 Протокол вступил в силу 01.09.2007 г. На 01.10.2008 г. Протокол ратифицировали 5 государств. 
в соответствии с последними достижениями науки в 1977 г. был создан Руководящий комитет по биоэтике (CDBI).

Согласно ст. 1 дополнительного Протокола 1998 г. к Конвенции о правах человека и биомедицине 1997 г. «О запрете клонирования человеческих существ», любое вмешательство, нацеленное на создание человеческого существа, генетически идентичного другому человеческому существу, живому или умершему, запрещено.

Дополнительный Протокол 2002 г. к Конвенции о правах человека и биомедицине 1997 г. применяется к трансплантации органов и тканей человека, осуществляемой в лечебных целях; положения Протокола 2002 г., применимые к тканям, применяются к клеткам, включая кровообразующие зародышевые клетки. Целью данного дополнительного Протокола является определение и защита прав доноров органов и тканей, как живых так и умерших, а также лиц, которым осуществляется пересадка органов и тканей человеческого происхождения. Дополнительный протокол 2002 г. состоит из преамбулы и 11 глав: цели и сфера применения; общие положения; удаление органов и тканей у живого лица; удаление органа и ткани у умерших лиц; имплантация органа или ткани, удаленных в целях, отличных от целей пожертвования для имплантации; запрещение извлечения финансовой выгоды; конфиденциальность; нарушения положений протокола; сотрудничество сторон; связь между настоящим протоколом и Конвенцией, пересмотр протокола и заключительные положения.

Дополнительный протокол 2005 г. к Конвенции о правах человека и биомедицине 1997 г. напрямую продолжает тему, начатую Нюрнбергским кодексом 1947 г. Целью этого акта является определение и гарантирование основополагающих прав в сфере биомедицинских исследований, в частности тех лиц, которые принимают участие в таких исследованиях ${ }^{21}$.

21 Как отмечается в пояснительном докладе к Протоколу 2005 г.: «Биомедицинские исследования являются мощным средством на службе здоровью человека. Свобода проведения исследований важна как сама по себе, так и в силу практической пользы, которую она приносит в области здравоохранения. В то же время необходима постоянная защита участников исследований. Участники жертвуют своим временем и могут подвергаться рискам и трудностям в ходе исследований. Следует уделять особое внимание защите их прав и недопущению злоупотребления их альтруизмом». // conventions.coe.int/ Treaty/RUS/Reports/Html/195.htm. Подробнее о Протоколе см. также: Юдин Б.Г. 
В решениях Европейского Суда по правам человека, многие из которых обладают силой прецедента будучи обязательными для дальнейших сходных решений, часто затрагиваются вопросы защиты соматических прав ${ }^{22}$. Например, дело Зет $(Z)$ против Финляндии (25 февраля 1997 г.), дело Серинг (Soering) против Великобритании (7 июля 1989 г.), дело Винтерверп (Winterwerp) против Нидерландов (24 октября 1979 г.), дело Во (Vo) против Франции ${ }^{23}$ (8 июля 2004 г.) и другие дела.

Остановимся подробнее на деле «Во против Франции». Суть дела состоит в следующем. В гинекологическое отделение больницы поступили две пациентки с одинаковыми фамилиями. Перепутав их, врач произвел в отношении заявительницы, пришедшей на обследование по беременности, действия, предназначенные для удаления контрацептивной спирали. Это привело к разрыву амниотического мешка и необходимости проведения аборта по медицинским показаниям. Кассационный суд Франции отказался квалифицировать как непредумышленное убийство действия врача, которые по его небрежности или неосторожности привели к смерти в утробе матери человеческого плода, хотя еще не жизнеспособного, но уже близкого к тому, чтобы стать таковым. Суд также отказался признать плод в утробе матери человеческим существом, пользующимся защитой уголовного права. Заявительница утверждала, что положение, при котором отсутствует

Этическое и правовое регулирование биомедицинских исследований: новый документ Совета Европы // Медицинское право. 2005. № 2; Тарасьянц Е.В. Международно-правовые аспекты защиты прав человека при проведении биомедицинских исследований // Московский журнал международного права. 2008. № 2 (70). С. 62-81; Крылова Н.Е. Некоторые этико-правовые вопросы проведения биомедицинских исследований на человеке // Государство и право. 2007. № 4. С. 32-39.

22 Подробнее см.: Дашян М. Биоэтика права в решениях Европейского Суда по правам человека // Бизнес-Адвокат. 2004. № 13.

23 Во против Франции // Бюллетень Европейского Суда по правам человека. Российское издание. 2004. № 12; Case Vo v. France, judgment 08.07.2004, № 53924/00 // Reports of Judgments and Decisions 2004-VIII. Судьи проголосовали следующим образом: 14 - «за», 3 - «против» (судьи: г-н Ресс (Германия), г-жа Муларони (Сан-Марино) и г-жа Стражничка (Словакия). См. также: Pichon Jakob. Does the Unborn Child Have a Right to Life? The Insufficient Answer of the European Court of Human Rights in the Judgment Vo v. France // 7 German Law Journal No. 4 (1 April 2006). 
защита еще не появившегося на свет ребенка со стороны уголовного права Франции, является недопустимым и образует нарушение ст. 2 Европейской конвенции о защите прав человека и основных свобод от 1950 г. ЕСПЧ не принял расширенного толкования права на жизнь неродившегося ребенка.

Рассмотренное дело затрагивает важное измерение права человека на жизнь: с какого момента начинается жизнь, с какого момента необходимо защищать жизнь ${ }^{24} \mathrm{C}$ момента зачатия, с пятого месяца после зачатия, с момента рождения и перерезания пуповины, с момента получения свидетельства о рождении? В ряде международных актов этот вопрос не уточняется. Исключением является Американская конвенция о правах человека (22 ноября 1969 г.), где в ст. 4.1 говорится: «Каждый человек имеет право на уважение его жизни. Это право защищается законом и, как правило, с момента зачатия». В ст. 2 Европейской конвенции о защите прав человека и основных свобод (Рим, 4 ноября 1950 г.) безотносительно к моменту появления у человека права на жизнь лишь констатируется: «Право каждого лица на жизнь охраняется законом». То же самое положение можно встретить в Африканской хартии прав человека и народов (Найроби, 26 июня 1981 г.). К каким негативным последствиям могут привести такие недомолвки, показало постановление по делу «Во против Франции», когда в практике Европейского Суда впервые был поставлен вопрос о наделении еще не родившихся детей, то есть человеческих плодов в утробе матери, всеми правами человека, гарантируемыми Конвенцией, но большинство судей ответили отрицательно.

Правовые проблемы, связанные со сменой пола, также обсуждаются в ЕСПЧ. Так, была рассмотрена жалоба от заявительницы из России, обжаловавшей действия властей (органов Минздрава), отказавших ей в выдаче нового паспорта перед операцией по смене пола 25 . До 1 января 1994 г. смена документов не составляла больших сложностей. В Институте психиатрии претенденты на смену пола проходили обследование, и компетентная комиссия давала заключение о необходимости операции тому или иному пациенту и рекомендовала смену паспорта. С этой бумагой пациент до операции обращался в отдел

24 Подробнее по этому вопросу см.: Романовский Г.Б. Юридическое определение момента возникновения права на жизнь // Государство и право. № 11. 2007.

25 Цит. по книге судьи в ЕСПЧ от России: Ковлер А.И. Антропология права: Учебник для вузов. М.: Издательство НОРМА, 2002. С. 441. 
ЗАГС по месту жительства, где вносились исправления в свидетельство о рождении, на основании чего выписывался новый паспорт. Как указано в материалах, приложенных к жалобе, с 1 января 1994 г. некоей «инструкцией» в России наложен запрет на смену паспортов транссексуалам до принятия соответствующего внутреннего закона о коррекции пола. На Украине же такой закон существует с 6 мая 1993 г. Вот и устремляются россияне, желающие поменять пол, а заодно паспорт и гражданство, в соседнюю страну. В случае обратившейся в Страсбург заявительницы операция была проведена полулегально и некачественно в украинской клинике, а в России ей было отказано в медицинской и правовой помощи. Жалоба была признана неприемлемой ratione temporis, т.e. события имели место до ратификации Россией Европейской конвенции. Однако в сходном случае «Ботелла против Франции» Суд признал вину Франции (решение от 25 марта 1992 г.) ввиду нарушения ст. 8 Европейской конвенции (право на частную жизнь).

Следует подчеркнуть, что не только государства вовлечены в процесс обсуждения актуальных вопросов биоэтики, но и мировые религии. Как отмечал профессор Ю.Е. Карлов, в современных международных отношениях все определеннее проявляет себя религиозный фактор, связанный с непосредственным участием в мировой политике различных религиозных объединений и организаций. Религиозно-правовые и морально-этические принципы мировых религий объективно укрепляют тенденцию к универсализации современного международного права ${ }^{26}$. Так, например, на юбилейном Архиерейском соборе Русской православной церкви в 2000 г. были приняты «Основы социальной концепции Русской Православной Церкви», где четко изложено мнение Русской православной церкви по вопросам клонирования, суррогатного материнства, трансплантологии и т.д. ${ }^{27}$. Также мировые религии официально выразили свое отрицательное отношение по вопросу клонирования человека ${ }^{28}$.

26 Карлов Ю.Е. Религия и международное право // В кн.: Международное право: Учебник / Отв. ред. Ю.М. Колосов, Э.С. Кривчикова. М., 2005. С. 572-574.

27 Основы социальной концепции Русской Православной Церкви. М., 2000. С текстом концепции можно ознакомиться на официальном интернет-сайте Московского патриархата <www.mospat.ru>. Подробнее о самой концепции см.: О социальной концепции русского православия / Под ред. М.П. Мчедлова. М., 2002. Также см.: Православие и проблемы биоэтики. М., 2001.

28 Заявление Церковно-общественного совета по биомедицинской этике при Московском патриархате «Об этической недопустимости клонирования человека» от 20.10.1999, 
В Российской Федерации общая картина правового регулирования вопросов, связанных с соматическими правами человека, такова: единого закона не существует, хотя проект федерального закона «О правовых основах биоэтики и гарантиях ее обеспечения» был внесен в Государственную Думу РФ в 1997 г., но 15 марта 2003 г. проект был отклонен в первом чтении ${ }^{29}$. Законопроект состоял из семи разделов: общие положения, правовые основы этики государственной политики в области здоровья и здравоохранения; правовые основы биоэтики отношений, возникающих в сфере здоровья; гарантии обеспечения биоэтики в вопросах, связанных с геномом человека; правовые основы биоэтики научных исследований; биоэтика в области трансплантации органов и тканей; организационные основы обеспечения гарантий в области биоэтики и заключительные положения.

Среди действующих законов, затрагивающих вопросы биоэтики, можно отметить Основы законодательства Российской Федерации об охране здоровья граждан 1993 г., Федеральные законы РФ «О трансплантации органов и (или) тканей человека» 1993 г., «О временном запрете на клонирование человека» 2002 г. В целях совершенствования национального законодательства в рассматриваемой сфере необходимо ратифицировать Конвенцию о правах человека и биомедицине Совета Европы с тремя протоколами.

В целом появление нового поколения прав человека - соматических прав - является объективным фактом. Требуется дальнейшее теоретическое исследование данного поколения прав с целью выработки научного и общего нормативного решения, а также дальнейшего уяснения, какие конкретно категории прав человека формируют это новое поколение прав. Многие государства пошли по пути разрешения на правовом уровне однополых браков, клонирования человека, эвтаназии, различных манипуляций с эмбрионами. Однако специфика нового поколения прав человека заключается в том, что международно-правовое поощрение развития соматических прав может повлечь необратимые и труднопрогнозируемые последствия для существования человеческого рода вообще. В настоящее время на международно-правовом

Мнение Святейшего Престола относительно клонирования человека в целях воспроизводства от 17.07.2003, Фетву шейха Юсефа аль-Карадави по вопросу клонирования от 2002 г. // Тексты документов см.: Овчинский В.С. Криминология и биотехнологии. М., 2005.C. 177-178, 186-189.

29 Постановление Государственной Думы РФ № 1253-III ГД // Правовая система «Гарант». 
уровне (ООН, Совет Европы) существует консенсус об ограничении соматических прав человека, особый вклад в принятие данного решения вносят данные биоэтики и позиции мировых религий.

\section{New Generation of Human Rights: Somatic Rights}

\section{(Summary)}

\section{Anna A. Abashidze*}

Aleksandr M. Solntsev ${ }^{* *}$

Scientific and technological progress, especially in the area of medicine, genetics, biology and chemistry gives a lot of possibilities and raises a lot problem to us. Now one can do euthanasia to himself or to his relatives, can choose the sex of his child, change his own sex. Many questions rise with the use of stem cells and with perspectives of cloning of the human being.

So in theory of law now we can speak about new generation of human rights which contains: right to die; human rights concerning its organs and tissues; sexual human rights (to seek, receive and impart information concerning sexuality, sexual education, the choice of a partner, to decide that the man should be sexually active or not, to decide the issue of voluntary sexual relations, marriage, the issue of legalizing prostitution, trafficking in pornography products and regulation situation of sexual minorities); reproductive human rights (positive: in vitro fertilization and negative: abortion, sterilization, contraception); right to change sex; right to clone an organism as a whole and individual organs; right to use drugs and psychotropic substances. UN, UNESCO and Council of Europe create some legal instruments (conventions, declarations etc.) in sphere of regulation of somatic human rights. These instruments are analyzing in the article.

\footnotetext{
*Anna A. Abashidze $-6^{\text {th }}$ year student of the medical faculty of the Russian Peoples' Friendship University.

** Aleksandr M. Solntsev - Ph.D. in Law, lecturer at the Law faculty of the Russian Peoples' Friendship University.
} 